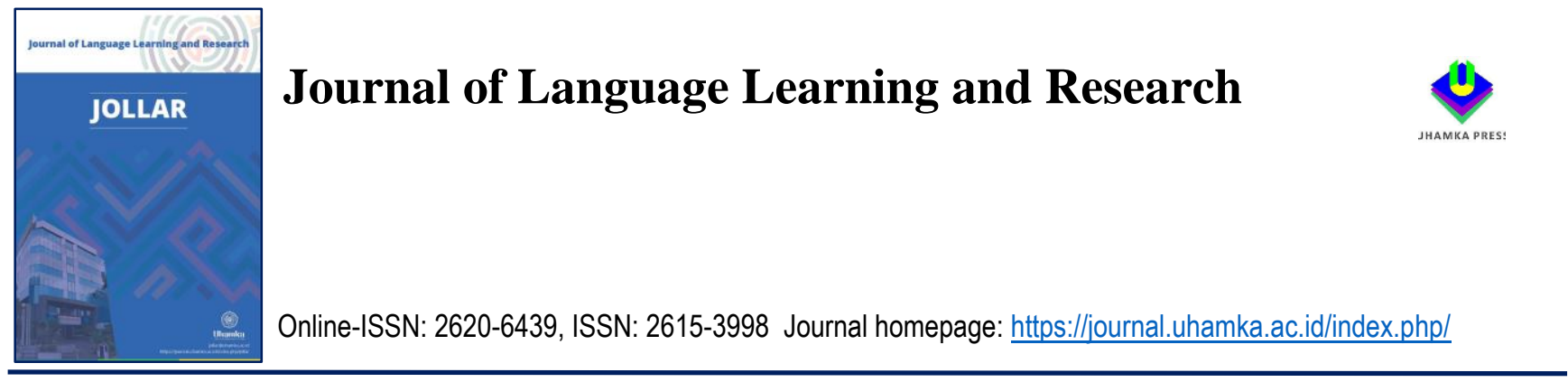

\title{
Realisasi Kesantunan Berbahasa dalam Novel Anak Rantau Karya Ahmad Fuadi
}

\author{
Ade Hikmat | Nani Solihati
}

How to cite : Hikmat, A., \& Solihati, N.,.2020. Realisasi Kesantunan Berbahasa dalam Novel Anak Rantau Karya Ahmad Fuadi. Journal of Language Learning and Research. 3(1). 40-56. https://doi.org/10.22236/jollar.v3i1.3704

To link to this article: https://doi.org/10.22236/jollar.v3i1.3704

\section{(2) Opened Access Article๘}

曲 Published Online on 11 Maret 2020

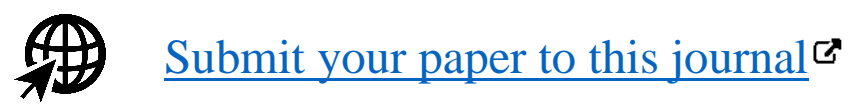

View Crossmark data ${ }^{\top}$ 


\title{
Realisasi Kesantunan Berbahasa dalam Novel Anak Rantau Karya Ahmad Fuadi
}

\author{
Ade Hikmat $\otimes^{1}$, Nani Solihati
}

Received: 20 Desember 2019 Accepted: 1 Maret 2020 Published: 11 Maret 2020

\begin{abstract}
Abstrak : Penelitian ini bertujuan menggali realisasi kesantunan berbahasa dalam novel Anak Rantau karya Ahmad Fuadi untuk dijadikan bahan pembelajaran satra di SMA. Selanjutnya kesantunan berbahasa yang ada di dalam novel diharapkan dapat dijadikan roll model dalam berbahasa secara santun. Metode penelitian yang digunakan ialah deskriptif kalitatif yang menjabaran semua hasil penelitian dalam bentuk deskriptiff sehingga memudahkan para pembaca dalam memahaminya, selain itu, peneleti menjadi instrmuen kunci penelitian. Dalam mengolah data novel peneliti dibantu dengan instumen penelitian yang mengacu pada teori kesantunan berbahas Leech. Sementara data yang didapatkan dari penulis dan guru tetang relalisasi kesantunan berbahasa dalam novel Anak Rantau karya Ahmad Fuadi yang akan dijadikan salah satu bahan pembelajaran sastra di SMA didapat dengan tekhnik wawancara dan rekam yang hasilnya ditransipkan dalam bentuk deskriptif. Realisasi kesantunan berbahasa dalam novel Anak Rantau karya Ahmad Fuadi terlihat dalam kutipan dialog tokoh Hepi, Attar, Zen, Kakek, Nenek, dan Pandeka Luko sebagai tokoh sentral dalam cerita. Dalam novel tersebut ditemukan 5 maksim kesantun berbahasa Leech yakni, maksim kearifan, pujian, kerendahan hati, kesepakatan, dan maksim simpati. Sementara maksim kedermawanan tidak ditemukan dalam novel tersebut.
\end{abstract}

Kata kunci: kesantunan berbahasa, bahan pembelajaran

Abstract: This study aims to explore the realization of language politeness in Ahmad Fuadi's Anak Rantau novel to be used as material for learning satra in high school. Furthermore, language politeness in the novel is expected to be used as a roll model in polite language. The research method used is descriptive qualitative which describes all research results in the form of descriptive so that it makes it easier for readers to understand it, besides, researchers become key instructors of the research. In processing novel data researchers are assisted with research instruments that refer to Leech's politeness theory. While the data obtained from the author and teacher about the relativity of language politeness in Ahmad Fuadi's Anak Rantau novel which will be used as one of the literature learning materials in high school is obtained by interviewing and recording techniques, the results of which are reproduced in descriptive form. The realization of language politeness in Ahmad Fuadi's Anak Rantau novel is seen in the quotations from the dialogues of the characters Hepi, Attar, Zen, Kakek, Nenek, and Pandeka Luko as the central figures in the story. In the novel, there are 5 maxims of Leech language politeness, namely, the maxim of wisdom, praise, humility, agreement, and sympathy maxims. While the maxim of generosity is not found in the novel.

\footnotetext{
$\triangle$ Nani Solihati

nani.solihati@gmail.com

Ade Hikmat

ade.hikmat@uhamka.ac.id

${ }^{1}$ Universitas Muhammadiyah Prof. DR. HAMKA
} 
Keywords: politeness of language, learning material

\section{PENDAHULUAN}

Kesopansantunan merupakan tata cara atau kebiasaan yang berlaku dalam masyarakat. Kesopansantunan ini disepakati atau ditetapkan bersama oleh suatu masyarakat tertentu sehingga kesopansantunan menjadi salah satu prasyarat yang disepakati oleh masyarakat bahasa. Kesopansantunan dapat dilihat dari berbagai segi dalam kehidupan sehari-hari. Salah satunya adalah kesopansantunan dalam berkomunikasi atau biasa disebut dengan kesantunan berbahasa. Kesantunan berbahasa dalam komunikasi tentunya menjadi kebutuhan bagi setiap masyarakat khususnya peserta didik. Komunikasi yang dilakukan baik secara lisan maupun tulisan sejatinya menggunakan kesantunan berbahasa dalam pengunaannya. Proses komunikasi secara santun menjadi harapan semua masyarakat terlebih harapan guruguru di sekolah. Karena dengan digunakan teknik penggunaan bahasa yang santun dapat mewujudkan komunikasi yang efektif serta meminimalisir terjadinya konflik antara penutur dan lawan tutur.

Pemahaman teori kesantunan berbahasa ini yang mendorong peneliti untuk menjadikan kesantunan berbahasa sebagai objek penelitian yang menjadikan karya sastra novel sebagai medianya. Hal tersebut dikarenakan secara umum, selain pengaruh boilogis serta lingkungan, bahan bacaan juga dapat mempengaruhi pengunaan bahasa seseorang, semakin banyak seseorang membaca bahan bacaan yang mengandung kesantunan, maka diharapkan akan semakin santun pula pengunaan kesantunan bahasa seseorang tersebut. Keadaan tersebut peneliti manfaatkan dengan menghadirkan penelitian kesantunan berbahasa di dalam sebuah karya sastra novel yang jumlah penikmatnya bisa dikatakan tidak sedikit.

Peneliti menggunakan media sebuah karya sastra novel yang best seller untuk menarik minat pembaca yang kemudian mengenalkan adanya kesantunan berbahasa di dalam dialog novel tersebut dengan cara menganalisis secara mendalam tentang maksim kesantuanan apa saja yang terdapat dalam novel. Temuan kesantunan tersebut selanjutnya diharapkan dapat dijadikan roll model penggunaan kesantunan berbahasa dalam berkomunikasi. Selain hal tersebut, saat ini penentuan penggunaan sebuah novel sebagai bahan ajar tentunya melewati berbagai klasifikasi-klasikasi tertentu sesuai dengan ketentuan yang berlaku, dalam hal ini novel yang digunakan sebagai bahan ajar tentunya bukan sembarang novel yang dapat begitu saja dipilih diantara ratusan koleksi di rak buku.

Pemilihan sebuah novel tentunya melewati beberapa klasifikasi diantanya bagaimana tema yang di angkat dalam novel tersebut, bagaimana jalan cerita di dalam novel, bagaimana amanat yang dapat diambil dalam cerita, apakah bahan bacaan 
sudah sesuai dengan tingkatan usia peserta didik, atau bahkan klasifikasi bagaimana kebahasaan yang digunakan dalam novel, apakah menggunakan bahasa santun kah, atau justru malah melanggar prinsip kesantunan.

Dalam keputusan ini lah tentunya peran guru di sekolah menjadi penting karena kegiatan literasi membaca bukan bagaimana peserta didik dapat memahami jalan cerita, bukan bagaimana peserta didik mendapatkan pesan moral dalam alur cerita yang ditampilkan saja, tetapi bagaimana bahan bacaan dapat berpengaruh positif terhadap kehidupan nyata peserta didik di lingkungan keluarga maupun asyarakat. Keputusaan tentang penggunaan sebuah novel tentunya harus dilakukan tinjauan seara lebih mendalam terhadap guru-guru di sekolah yang berpengalaman secara langsung melihat perkembangan pembelajaran di dalam kelas.

Pengaruh positif dari bahan bacaan ini bisa di dapatkan diantaranya dengan menghadirkan suatu kesantunan berbahasa di dalam sebuah novel yang diharapkan dapat dijadikan roll model dalam kehidupan sehari-hari. Kehadiran novel yang mengandung kesantunan berbahasa ini tentunya merupakan hasil dari kecerdasan komunikatif seorang penulisnya. Kecerdasan komunikasi meliputi kemampuan seseorang dalam menggunakan maupun mengolah gagasan yang akan disampaikan kepada orang lain melalui kata-kata atau bahasa. Seseorang yang memiliki kecerdasan komunikasi yang baik dapat berkomunikasi secara efektif baik lisan maupun tulisan.

Hal ini sesuai dengan pendapat Tagor (2008:179) yang menyatakan bahwa kecerdasan komunikatif merupakan "tact knowledge" atau sesuatu yang telah dimapani penuturnya baik dari peranti simbolik bahasanya, norma-norma tata krama dan komunikatifnya, bahkan norma budaya penutur dan teman tutur, segalanya pada tahap maksim. Dari pendapat ini dapat disimpulakan bahwa seorang penulis novel memiliki kecerdasan komunikasi yang tinggi, karena ia dapat mentransformasikan segala idenya dalam bentuk dialog-dialog cerita yang variatif terlebih dengan menghadirkan kesantunan berbahasa di dalamnya sehingga novel tersebut memilki nilai tambah baru selain berfungsi sebagai hiburan, dapat pula dijadikan sebuah pembelajaran yang dapat menjadikan kesantunan sebagai roll model penggunaan bahasa yang santun. Hal ini tentunya memerlukan pendapat langsung dari penulis tentang karya sastra nya yang dipilih peneliti untuk dikaji dalam aspek kesantunan berbahasa serta berencana menggunakan novelnya sebagai salah satu bahan materi pembelajaran di dalam kelas khusunya di SMA.

Kesopanan dapat dilihat dari berbagai segi dalam kehidupan sehari-hari. Salah satunya adalah kesopansantunan dalam berinteraksi dan berkomunikasi. Pada hakikatnya tujuan dalam berkomunikasi ialah menjaga atau memelihara hubungan sosial penutur dan petutur. Berangkat dari tujuan inilah kesopansantunan berkomunikasi atau biasa disebut kesantunan berbahasa harus dipegang setiap peserta 
tutur. Leech dalam Pranowo memandang prinsip kesantunan sebagai "piranti" untuk menjelaskan mengapa penutur sering bertutur secara tidak langsung (indirect) dalam mengungkapkan maksudnya. (Pranowo, 2012: 102 ) Bertutur secara tidak langsung merupakan bagian dalam prinsip kesantunan berbahasa.

Pranowo (2012: 15) berpendapat bahwa berbahasa dan berprilaku santun merupakan kebutuhan setiap orang, bukan sekadar kewajiban. Seseorang berbahasa dan berprilaku santun sebenarnya lebih dimaksudkan sebagai wujud aktualisasi diri. Sehingga penting dilakukan sebagai Pendapat Pranowo berhubungan dengan pendapat Chaer yang menyatakan bahwa kesantunan berbahasa diperoleh dari belajar berbahasa, sedangkan etika berbahasa bersumber dari "budi pekerti" bertingkah laku (Pranowo 2012: 15). Berbahasa dan berprilaku santun sejatinya merupakan keuntungan bagi penutur itu sendiri. Karena hal tersebut dapat meminimalkan adanya konflik saat pertuturan.

Leech (1993: 206-207) berpendapat bahwa prinsip kesantunan menyangkut hubungan antara 2 partisipan, yaitu diri (self) dan pihak lain (other). Diri mengacu kepada penutur dan pihak lain mengacu pada pendengar. Leech membagi prinsip kesantunannya menjadi 6 maksim. Keenam maksim tersebut adalah sebagai berikut: pertama, maksim kearifan atau maksim kebijaksanaan bahwa para peserta pertuturan hendaknya berpegang pada prinsip untuk selalu mengurangi keuntungan dirinya sendiri dan memaksimalkan keuntungan pihak lain dalam kegiatan bertutur. Apabila di dalam bertutur orang berpegang teguh pada maksim kearifan, ia akan dapat menghindarkan sikap dengki, iri hati, dan sikap-sikap lain yang kurang santun terhadap mitra tutur.

Kedua, maksim kedermawanan, dalam maksim ini para pertuturan diharapkan dapat menghormati orang lain. Penghormatan tersebut akan terjadi apabila orang dapat mengurangi keuntungan bagi dirinya sendiri dan memaksimalkan keuntungan bagi pihak lain. Ketiga, maksim pujian ialah bahwa orang dapat dianggap santun apabila dala bertutur selalu berusaha memberikan pujian atau penghargaan kepada pihak lain. Dengan maksim ini diharapkan agar para peserta pertuturan tidak saling mengejek, saling mencaci, atau saling merendahkan pihak yang lain.

Keempat. maksim kerendahan hati ini peserta tutur diharapkan dapat bersikap rendah hati dengan cara mengurangi pujian terhadap dirinya sendiri. Orang akan dikatakan sombong dan congkak hati apabila di dalam kegiatan bertutur selalu memuji dan mengunggulkan dirinya sendiri.Kelima, maksim kesepakatan menekankan agar para peserta tutur dapat saling membina kecocokan atau kesepakatan di dalam kegiatan bertutur. Apabila terdapat kesepakatan dan kecocokan antara diri penutur dan mitra tutur dalam kegiatan bertutur, masing-masing dari mereka dapat dikatakan bersikap santun. 
Keenam, maksim simpati ini diharapkan agar peserta tutur dapat memaksimalkan sikap simpati antara pihak yang satu dengan pihak yang lain. Sikap antipati terhadap seorang peserta tutur akan dianggap sebagai tindakan yang tidak santun. Penggunaan maksim kesantunan berbahasa dapat terlihat dalam bahasa lisan maupun bahasa tulis khusunya karya sastra misalnya novel. Bentuk kesantunan berbahasa ini terealisasikan dalam dialog-dialog tokoh yang dapat dikaji berdasarkan konteks pertuturan. Misalnya dalam novel Anak Rantau karya Ahmad Fuadi. Novel tersebut mengandung bentuk kesantunan berbahasa Leech dalam dialog tokoh Hepi, Zen, Attar, serta Kakek, Nenek, Pandeka Luko sebagai tokoh yang dominan dalam cerita.

Selanjutnya, novel yang syarat dengan kesantunan berbahasa ini dapat diajukan sebagai bahan ajar di SMA. Hal tersebut dapat memberikan nilai tambah kepada peserta didik, karena selain memahami karya sastra terkait dengan isi bacaan, proses pembelajaran juga dapat memberikan pemahaman tentang adanya bentuk kesantunan berbahasa dalam novel dengan harapan akhir, hal tersebut dapat dijadikan sebagai roll model penggunaan kesantunan berbahasa dalam keseharian berkomunikasi para peserta didik. Penelitian serupa telah dilakukan sebelumnya ialah Yola Maulina, dkk.pada tahun 2015 dengan judul Kesantunan Berbahasa Dalam Novel 99 Cahaya di Langit Eropa Karya Hanum Salsabiela Rais dan Rangga Almahendra. Dalam novel yang dianalisis hanya sedikit tuturan maksim kesantunan berbahasa yang ditemukan. Hal tersebut dikarenakan cerita dalam novel lebih dominan mengisahkan tentang sejarah Islam di Eropa. Maksim kesantunan berbahasa yang dominan ialah maksim kedermawanan dan pujian. Sementara maksim yang tidak ditemukan ialah maksum kerendahan hati.

Penelitian berikutnya ialah Iin Alviah tahun 2014 dengan judul penelitian Kesantunan Berbahasa Dalam Novel Para Priyayi Karya Umar Kayam menemukan kesantunan berbahasa Leech dilihat dari realisasi tindak tutur yang dalam novel Para Priyayi karya Umar Kayam terbagi dalam lima kelompok tindak ilokusi, yakni representatif, direktif, komisif, ekspresif, dan asertif.

Selanjutnya Dina Etikawati dalam Kesantunan Tuturan antar Tokoh dalam Novel Nama Ku Matahari Karya Remy Sylado, hasil penelitiannya menunjukkan terdapat beberapa jenis tindak tutur yang terdapat di dalam novel seperti tindak tutur representatif, tindak tutur direktif, tindak tutur komisif, tindak tutur ekspresif, dan tindak tutur deklarasi. Temuan lain dari penelitian ini yakni adanya tuturan yang tergolong mematuhi prinsip kesantunan dan melanggar prinsip kesantunan. Tuturan antartokoh dalam novel berdasarkan skala kesantunan diketahui bahwa ada tuturan dengan kategori tuturan santun dan tuturan kurang santun di dalam novel Namaku Mata Hari karya Remy Sylado 
Penelitian berikutnya dilakukan oleh Sara Beden \& Indriawati Zahid dengan judul Analysis of leech (1983) and Grice's (1975) Politeness: The Pattern and Structural of Politeness Language Manifestation In The Novel Melunas Rindu. Hasil temuan penelitiannya ialah adanya kombinasi antara prinsip kesopanan leech dengan prinsip kerja sama Grice. Hal tersebut dikarenakan bahwa, prinsip kesopanan tidak bias berdiri sendiri pembentukannya. Kajian juga memperlihatkan bahawa struktur peristiwa kesopanan berbahasa disampaikan dalam struktur yang bervariasi. Selanjutnya ditemukan adanya penggunaan pola-pola tertentu dalam berkomunikasi, tetapi struktur peristiwa dalam setiap peristiwa komunikasi tersebut berbeda antara satu sama lain.

Dari keempat penelitian yang sudah dilakukan di atas, peneliti melakukan penelitian ini dengan novelty dalam penelitian ini ialah penggunaan novel Ahmad Fuadi yang karya dan popularitas penulisnya memang diburu para penikmat sastra. Hal ini dikarenakan, karya sastra Ahmad Fuadi selalu dinantikan penikmatnya dengan bukti bahwa karya nya bestnasional. Selain itu, psikologis tokoh, latar, alur, serta penokohan adalah sebuah angina segar dalam jenis karya sastra. Kesantunan berbahasa dalam dialog tokoh sentral dengan usia remaja menjadi daya tarik dalam memutuskan Anak Rantau ini sebagai bahan ajar pembelajaran sastra di SMA.

Tujuan penelitian ini ialah Untuk menganalisis kesantunan berbahasa di dalam novel "Anak Rantau” karya Ahmad Fuadi yang kemudian diharapkan kesantunankesantunan tersebut dapat dijadikan roll model dalam berbahasa secara santun. Selain itu pemilihan sebuah novel yang sarat kesantunan berbahasa dapat dijadikan salah satu materi ajar di dalam kelas.

\section{METODE}

Dalam penelitian, metode yang digunakan ialah dekripstif kualitatif. Menurut Bogdan dan Taylor dalam Esti (2012:7) mendefinisikan kualitatif sebagai prosedur penelitian yang menghasilkan data deskriptif berupa kata-kata tertulis atau lisan dari orang-orang dan perilaku yang dapat diamati; pendekatan ini diarahkan pada latar dan individu secara holistik (utuh).

Penelitian kualitatif dalam hal ini adalah akumulasi data dasar dalam cara deskripsi yang menjadikan peneliti sebagai instrumen kunci. Afrizal (2015:13) berpendapat bahwa penelitian kualitatif didefinisikan sebagai metode penelitian ilmuilmu sosial yang mengumpulkan dan menganalisis data berupa kata-kata (lisan maupun tulisan) dan perbuatan- perbuatan manusia serta peneliti tidak berusaha menghitung atau mengkualifikasikan data kualitatif yang diperoleh dan dengan demikian tidak menganalisis angka-angka. 
Metode kualitatif yang digunakan ialah teknik analisis data. Yang dilakukan secara siklus dimulai dari tahap kodifikasi atau tahap pemberian kode pada data-data yang ditemukan, tahap penyajian data ke dalam tabel pengumpulan data, dan sampai pada tahap penarikan kesimpulan atau verifikasi setelah dilakukannya analisis data sesuai dengan teori prinsip kesantunan berbahasa Leech. Peneliti juga menggunakan teknik wawancara dan simak catat untuk memperoleh data di penulis dan guru-guru di beberapa sekolah di beberapa wilayah di Jakarta.

\section{TEMUAN DAN PEMBAHASAN}

\section{a. Temuan Unsur Intrinsik}

Temuan penelitian berlandaskan pada unsur intriksik novel yaitu : ema novel ialah petualangan anak rantau yang datang ke di kampung ayahnya sendiri. Alur cerita menggunakan alur maju dengan pengisahan dimulai dengan petualangan akhir tokoh Hepi, Atar, dan Zen yang terlibat dalam pengungkapan kasus narkotika di kampung Durian yang selanjutnya disambung dengan cerita perjalanan tokoh Hepi yang harus tinggal sebagai anak rantau di kampung halamannya sendiri. Latar cerita ialah di Jakarta sebagai tempat tinggal keluarga Martiaz yang mempunyai anak bernama Hepi dan Dora yang juga bermata pencaharian di Jakarta. latar berikutnya ialah di kampung Tanjung Durian sebagai latar yang dominan dalam cerita, hal ini dikarenakan tokoh utama Hepi tinggal di kampung ini sebagai hukuman dari sang ayah karena tidak naik kelas keika sekolah di Jakarta. latar suasana begitu beragam, misalnya senang, ketika Martiaz, ayah Hepi tidak memberikaan langsung hukuman ketika ia mengetahui raport Hepi yang kosong tidak berisi. Perasaan senang misalnya ketika Hepi dengan lebih mudah mengumpulkan rupiah ketika menjadi kurir Bang Lenon. perasaan sedih dan marah misalnya ketika Hepi ditinggalkan ayahnya ke Jakarta. serta perasaan takut dan pasrah misalnya ketika Hepi dan kedua temannya berada di ambang kehidupan karena harus berhadapan dengan anak buahnya Lenon sebagai orang yang terlibat dalam kasus narkotika.

Unsur intrinsik berikutnya ialah tokoh dan penokohan dalam noel diantanya tokoh Hepi yang menjadi tokoh utama, ia memiliki penokohan sebagai seorang siswa SMP yang kutu buku, memiliki rasa ingin tahu yang tinggi, pintar, dan tepat janji. Attar dengan penokohan sebagai orang yang ahli dalam membidik dan perduli terhadap temannya. Zen digambarkan tokoh penyayang binatang, Datuk Marajo Labiah (kakek) sebagai orang disiplin, pemarah, disegani dan dituakan di kampung Tanjung Durian. Salisah (Nenek) adalah seorang yang penyayang. Martiaz, adalah ayah Hepi merupakan seorang yang pandai olahraga bersilat serta jujur. Pandeka Luko merupakan pahlawan di masa lampau, Ibu Ibet, Puti, dan tokoh lainnya. Sudut pandang 
dalam ceringga menggunakan sudut pandang orang ke tiga serba tahu membuat penulis menuliskan semua gambaran peristiwa yang terjadi dan juga penokohannya. Gaya bahasa yang digunakan ialah gaya bahasa personifikasi dan gaya bahasa simile yang diganbarkan dalan beberapa dialog tokoh maupun dalam prolog cerita. Amanat yang dapat diambil ialah 1) Tidak lupa untuk kembali pulang ke kampung halaman ketika pergi merantau. 2) Menggunakan kesantunan dalam berbahasa terhidar dari konflik. 3) Membaca buku sejak dini dapat memperluas wawasan.4) Pelajaran agama dan pendidikan karakter memang seharusnya diajarkan kepada anak sejak dini. 5) Apa yang ditaman, itulah buah yang akan dituai. 6) Masa lalu adalah guru yang paling berharga. Amanat muncul dari beberapa peristiwa penting dalam cerita.

\section{b. Temuan Unsur Ekstrinsik}

Unsur ekstrinsik merupakan unsur pembangun novel yang berada di luar teks. Biasanya unsur ini berhubungan dengan ilmu-ilmu lain seperti ilmu politik, biografi dan psikologi pengarang, ilmu ekonomi, ilmu sosial, bahkan kesantunan berbahasa yang ada dalam novel.

Kamini (2011: 14) berpendapa bahwa unsur ekstrinsik adalah unsur-unsur yang berada di luar karya sastra, tetapi secara tidak langsung mempengaruhi sistem organisme karya sastra atau unsur-unsur yang mempengaruhi bangun cerita sebuah karya sastra, namun ia sendiri tidak menjadi bagian di dalamnya. Misalnya prinsip kesantunan bebahasa yang ada dalam kutipan dialog novel Anak Rantu karya Ahmad Fuadi ialah sebagai unsur ekstrinsik novel yang berada di luar cerita namun mempengaruhi bangun cerita tersebut. Berikut temuan penggunann kesantunan berbahasa dalam dialog-dilaog tokoh.

1) Maksim kearifan

Maksim kearifan itemukan dalam beberapa dialog antar tokoh, diantanya dalam dialog sebagai berikut: tokoh Martiaz dengan arif berkata kepada Hepi anaknya. Kearifan sebagai Ayah diutarakan melalui ungkapan yang mengigatkan Hepi untu"Martiaz mengucapkan sebuah salam, assalamualaikum yang serak. Tiada jawaban dari atas rumah panggung itu, hanya terdengar galosoh-pesoh gerakan kaki.......... Salami kakek, kata Martiaz, mendorong punggunggnya maju. Hepi ragu-ragu maju memegang tangan gemuk kakeknya dan menempelkan di keningnya ". hlm. 20.

Tokoh Martiaz yang mencontohkan sikap yang baik terhadap anaknya termasuk dalam maksim kearifan. Orang tua memang suda selayaknya seperti yang 
dilakukan tokoh Martiz ketika datang berkunjung ke rumah Kakek. Maksim kearifan berikutnya terdapat dalam kutipan ketika Kakek mengajak anak-anak untuk berlatih bersilat dan berkesenian Minang.

Datuk : "Besok malam kalian semua pakai celana galembang untuk bersilat, kata Kakek suatu sore.

Hari Sabtu malam, Kakek mengajak anak-anak ke lapangan di depan surau untu belajar bersilat dan berkesenian Minang. Dia percaya kombinasi ilmu agama dan adat ini adalah bekal penting seorang anak Minang untuk hidup. Selain mendatangkan dari sasaran silat di kampung ini, Kakek ikut pula turun langsung mengajar silat.

Di awal latihan Kakek berpesan. Pasanglah niat baik-baik di hati kalian. Silt minang ini bukan untuk kalian berkelahi. Sebaliknya. Lahia silek mencari kawan. Batin silek mencari Tuhan. Secara lahirnya, silat itu untuk mencari kawan. Secara batinnya, silat itu untuk mencari Tuhan". Hlm. 146-147.

Sikap Datuk yang memberikan wejangan kepada muridnya-muridnya termasuk dalam maksim kearifan. Karena dengan disampaikannya wejangan tersebut diharapkan para muridnya dapat menambah pengetahuan serta sikap yang diharapkan Datuk.

2) Maksim kedermawanan

Tidak ditemukan maksim kedermawanan dalam kutipan dialog.

3) Maksim Pujian

Maksim pujian dilakuakan oleh Martiaz kepada Dora, anak perempuannya. Dora merupakan anak yang sangat bisa diandalkan, hanya beberapa kali diajarkan memasak oleh Martiaz, Dora dengan lihai dapat memasak di dapur tanpa diperintah. Masakannya mendapat sambutan yang hangat dari Martiaz yang disampaikan melalui pujian. Pujian tersebut termasuk dalam maksim pujian. Berikut kutipannya:

Dora :

"Sesekali sarapan bareng dong, Yah. Ada nasi goring Padang pakai petai, nih." Dora, anaknya berteriak sambil mengacau-ngacau isi kuali di depannya".

Martias :

"Asal rasanya tidak kalah saja sengan buatan Ayah, ya" Martiaz menjawab dengan tersenyum sambil bergegas meraih handuk". "Anak yang tahu diuntung. Katnya lirih. Sambil mengguyur badannya. Martiaz 
bersyukur karena hanya perlu dua kali saja mengajari Dora memasak. Setelah itu, gadis muda ini mengambil alih kekuasaan dapur dari tangannya tanpa banyak cincong. Baginya, ini salah satu ukuran kesuksesan dalam mendidik anak gadis. Dengan handuk menggantung di leher dan ujung rambut masih meneteskan air, dia berdiri di depan cermin, memangkas jambangnya yang mulai menyemak dan bulu hidungnya yang menyembul-menyembul. Dia ingin klimis di hari tidak biasa ini”.

"Ondeh mandeh, pedas tapi enak. Bisa tuambah tiga piring ini, puji Martiaz sambil menyendok lagi nasi yang memrah meriah karena diaduk dengan beberapa sendok cabai giling segar". Hlm. 6.

Maksim pujian berikutnya yang juga terdapat maksim kesepakatan di dalamnya terlihat dalam kutipan berikut:

Datuk : "Sebulan lagi kita aka nada acara gabungan khatam kaji beberapa surau yang berdekatan. Kalau melihat perkembangan bacaan wa'ang, sudah pantas nanti ikut khataman, kata Kakek suatu kali. Hepi mengiyakan saja dengan menganggu". Hlm, 110-111.

Pujian Kakek terhadap bacaan mengaji Hepi termasuk dalam maksim pujian. Sementara sikap Hepi yang mengiyakan ucapan kakeknya termasuk dalam maksim kesepakatan. Maksim pujian berikutnya ialah pada kutipan saat Bongkar memberikan pujian terhadap suara adzan Hepi termasuk dalam maksim pujian kesantunan berbahasa. Pujian tersebut disambut hangat oleh Hepu dengan berubahnya muka Hepi menjad merah karena senang. Maksim tersesbut terdapat dalam kutipan berikut:

"Suatu sore, selepas Asar di surau, Hepi bergegas ke pos ronda yang lumayan ramai oleh anak-anak muda yang mengobrol mengelilingi Lenon dan Bongar. Demi melihat Hepi datang, Bongkar langsung menyambut,

Bongkar: Lumayan juga suara wa'ang azan tadi, Hepi. Sejenak Hepi merasa mukanya merah karena senang. Sejak beberapa minggu ini memang dia merasa azannya semakin merdu”. Hlm 158.

4) Maksim kerendahan hati

Maksim kerendahan hati terdapat dalam kutipan sebagai berikut :

"Tapi, detik selanjutnya, sesosok tubuh keluar dari balik semak sambil bersungut-sungut berang. Dia menggaruk-garuk keningnya yang kena peluru nyasar itu. 
Hepi : Hoi, sembarang saja main tembak, katnya kesal".

Attar : "Maaf-maaf, Indak sangajo. Tidak sengaja, kata Attar terburu-

buru mendekat ke orang bertopi merah itu". Hlm, 26.

Meskipun Attar tidak sengaja melesatkan pelurunya ke Hepi, Ia dengan rendah hati meminta maaf kepada Hepi. Hal tersebut menandakan bahwa Attar mempunya kerendahan hati sehingga permintaan maafnya termasuk pada maksim kesantunan berbahasa maksim kerendahan hati. Kutipan berikunya ialah Ketika kakek melarang hepi bermain dengan Lenon preman kampung, dengan tenang dan hormat menjawab Kakeknya. Hal tersebut menandakan bahwa Hepi tetap berprilaku hormat dan sopan meskipun kekeknya melarang nya untuk bermain dengan Lenon. Jawaban Hepi pada akhirnya membuat kakeknya tidak dapat berpanjang lebar menasihatinya. Perilaku Hepi tersebut termasuk dalam maksim kerendahan hati. Berikut kutipannya:

Datuk Marajo Labiah: "wa'ang jauh-jauh tinggal di kampung tidak untuk bergaul dengan preman, suara kakeknya terdengar geram. Wajahnya keruh. Nenek memandanginya dalam-dalam dengan wajah khawatir.

Hepi : "Tapi bang Lenon itu preman tobat, Kek. Sudah mulai pergi ke surau." Datuk Marajo Labiah: "Belum bisa aku percaya sama dia." Hepi ingin berbohong untuk menutupi tujuannya mencari uang guna pulang ke Jakarta. Tapi sekelebat kemudian jawaban yang lebih baik muncul begitu saja. Ceramah kultum kakeknya sendiri.

Hepi : "Kek, aku sebetulnya sedang belajar dari kultum Kakek tempo hari. Kakek bilang, kalau kita harus husnudzon, selalu berprasangka baik pada orang lain. Hati orang hanya Allah yang tahu, kata Kakek tempo hari. Balas Hepi sambil bercerita bengkel kerajinan dan kegiatan jualan Lenon."

Datuk Marajo Labiah: "Lunak sekali lidah wa'ang membuat alasan. Pokonya kau tidak boleh main dengan preman. Hardiknya. Namun setiap hardikan Kakek bias dijawab Hepi dengan tenang dan hormat." Hkm. 81-82.

Maksim kerendahan hati berikutnya ialah terjadi anatara tokoh Lenon dan Hepi dengan kutipan sebagai berikut:

"Ketika Hepi pamit pulang, Bang Lenon menyelipkan beberapa lembar uang ke sakunya.

Lenon : "Terimo kasih, yo”. 
Setelah agak jauh dari Bang Lenon, cepat-cepat ia periksa isi sakunya. Ada selembar uang sepuluh ribu untuk pekerjaan yang ahanya setengah jam. Malam itu dengan sukacita dia selipkan uang itu ke tabungan betungnya. Dia membayangkan, kalau terus menjadi kurir Bang Lenon, dalam lima bulan saja dia sudah bias terbang ke Jakarta. Hepi mengucap Alhamdulillah". Hlm. 146.

Sikap Lenon kepada Hepi yang menyelipkan uang, serta mengucapkan terima kasih atas bentuan Hepi hari itu termasuk dalam kesantunan berbahasa maksim kerendahan hati. Hal tersebut dikarenakan tokoh Lenon yang digambarkan sebagai seorang preman yang usianya lebih tua, juga meskipun ia yang memberikan pekerjaan kurir itu kepada Hepi. Lenon tetap dengan kerendahan hainya mengucapkan terima kasih sebagai tanda penghargaan terhadap Hepi yang telah melaksanakan tugasnya dengan baik kala itu.

5) Maksim kesepakatan

Maksim kesepakatan pertama terdapat dalam kutipan sebagai berikut, Martiaz:

"Pagi-pagu Martiaz menahan tangan Hepi yang sudah siap berlari untuk bermain. Nak, berkemaslah, kita pulang kampung hari ini”.

Mata hepi membesar dan mulutnya menganga lebar, hampir-hampir tidak percaya dengan pendengarannya. Entah sudah berapa ratus kali dia merengek meminta diajak liburan ke kampung. ......., Dengan sukacita Hepi menjejalkan baju, mainan, dan buku yang banyak ke dalam tas besar yang akan dimasukkan ke bagasi pesawat. Adapun ransel merah yang akan dipanggulnya berisi komik detektif Conan, kungfu Boy serta dua barangnya yang paling berharga: sebuah teropong hasil perburuan di pasar loak dan radio HT hadiah dari ayahnya". Hlm. 13-14.

Ajakan Martiaz kepada Hepi untuk pulang kampung disambut sukacita oleh Hepi. Hal tersebut dikarenakan perihal keinginan Hepi yang memang sudah ingin sekali pulang kampung, baru dikabulkan ayahnya, bahkan ketika nilai raportnya kosong melompong tidak berisi. Ajakan Mertiaz disepaki Hepi yang terlihat dari reaksi Hepi yang dengan suka cita Hepi mempersiapkan segala kebutuhannya untuk dibawa dan dimasukan ke dalam tas. Kutipan maksim kesepakatan berikutnya terdapat pada respon anggukan Martiaz atas pertanyaan Hepi. Hal tersebut manandakan bahwa Martiaz sepakat atas harapan Hepi yang menginginkan naik pesawat kembali ketika pulang ke Jakarta nantinya. Berikut kutipannya: 
Hepi : "Yah, nanti kita pulang ke Jakarta naik pesawat lagi kan? Tanyanya penuh harap. Ayahnya mengangguk. Hepi jatuh cinta dengan sensasi terbang." Hlm. 16.

6) Maksim simpati

Maksim simpati terdapat dalam kutipan antara Hepi dan Pandek Luko sebagai berikut:

Hepi : “Assalamualaikum, Pandeka, kata Hepi dengan suara meleot seperti radio kehabisan baterai.

Pandeka : dia membalas salam pelan. Mulutnya membuka dan Hepi bias melihat gigi taringnya muncul sekilas. Memang agak runcing. Inikah yang disebut-sebut kawankawannya sebagai gigi pemakan binatang malam? Mata harimaunya menikamnikam. "Apa yang wa'ang sedihkan, Anak Bujang? Suaranya serak dan dalam, seperti dari masa lalu. ....,

Pelan-pelan buntalan demi buntalan kesedihan masa lalunya terlepas ikatannya, dan terserak di dalam hatinya. Perasaan bagai awan kelabu yang berat dan tebal, yang kemudian jatuh jadi hujan rintik, kemudian menderas. Hepi tidak bisa percaya, tibatiba matanya basah, diiringi sedu sedan segala. Keterlaluan Pandeka ini, rutuk Hepi dalam hati. Hanya satu pertanyaan saja, dan pertanyaan pertama itu telah membobol jantung hatinya. Padahal, dia dating bukan buat ditanya, melainkan untuk bertanya, untuk minta tolong.

Hepi : "Karena merasa ditinggalkan, Pandeka...., dan merasa marah dan dendam, tambah Hepi"

Pandeka : "Kita boleh ditinggalkan, tapi jangan mau merasa ditinggalkan. Kita boleh dibuang, tapi jangan merasa dibuang. Dulu aden juga merasa jadi orang yang terbuang dan korban. Tapi tidak lagi, kata Pandeka Luko."

Hepi datang bukan untuk Tanya-jawab tidak jelas ini.

Hepi : “Aku ingin minta tolong, Pandeka, kata Hepi."

Pandeka untuk pertama kalinya bergerak, telunjuknya diangkat di depan wajahnya, mengisyaratkan Hepi untuk diam. Lalu dia bergerak gesit dan ringan untuk orang tua seumur dia, membuka pintu rumahnya.

Pandeka : "Pulanglah dulu. Dating lagi besok malam, jangan bawa siapa-siapa, katanya dengan dingin.

Hepi baru tersadar, dia sudah lama di sini, jam tik tok sudah berputar hamper setengah jam. Jangan sampai Attar dan Zen memukul tabuh, dan menghidupkan pelantang mulai berhalo-halo untuk meminta bantuan warga. 
Pandeka : "Ini bawa bawa lagi surat wa'ang, kata Pandeka mengangsurkan amplop yang dia selipkan kemarin". Hlm. 235-236.

Sikap simpati Pandeka yang ditunjukkan kepada Hepi diutarakan Pandeka dengan pertanyaan sebagai tanda ia perduli terhadap apa yang dirasakan Hepi yang sebelumnya diutarakan Hepi lewat sepotong surat pendek yang diberikannya kepada Pandeka. Baru satu pertanyaan yang meluncur kepada Hepi, perasaan Hepi yang sebelumnya dipenuhi kesedihan yang amat mendalam, runtuk menjadi butiran air mata yang tidak dapat terbendung lagi.

\section{c. Hasil wawancara}

Berdasarkan hasil wawancara dengan guru-guru SMA dan SMK di beberapa wilayah Jakarta dan Bekasi. Sebagian besar guru, belum mengetahui tentang teori kesantunana berbahasa Leech, sehingga kami melakukan pemahaman terlebih dahulu tentang teori tersebut. Berkaitan dengan penggunaan karya sastra sebagai bahan ajar ,setiap guru memiliki karakteristik tertentu dalam menentukannya yang disesuaikan dengan silabus yang digunakan. Misalnya pada guru di SMK, guru tersebut mengharuskan bacaannya disesuaikan dengan tema tertentu yang terkait, misalnya isinya berisi cerita sejarah, pengarangnya merupakan sastrawan Indonesia, tidak mengandung unsur sara, dan lain-lain.

Pemilihan novel sebagai bahan ajar tentunya melalui proses yang cukup panjang. Hal tersebut dilakukan guna menyiapkan secara maksimal bagaimana kebemanfaatan baha ajar terhadap peserta didik. Kebermanfaatan tersebut terlihat dalam beberapa hal, diantaranya nilai-nilai yang terdapat dalam cerita, bagaimana kaitannya cerita dengan kehidupan realita, serta bagaimana karya sastra tersebut dapat dijadikan roll model dalam kegiatan sehari-sehari seperti halnya dalam penggunaan kesantunan berbahasa dalam berkomunikasi. Minimnya penggunaan kesantunan berbahasa anak dalam berkomunikasi menjadi salah satu jawaban hadirnya bentuk realisasi kesantunan berbahasa dalam novel Anak Rantau karya Ahmad Fuadi sebagai bahan ajar pembelajaran sastra di SMA. Penanaman kesantunan berbahasa melalui karya sastra khusunya novel terkait, diharapkan menjadi solusi dari permasalahan yang terjadi di lingkungan sekolah yang berkaitan dengan minimnya penggunaan kesantunan berbahasa peserta didik dalam berdialog.

Berkaitan dengan latar belakang penyusunan novel Anak Rantau diperkirakan menggunakan latar Sumatera disebabkan latar tempat dari penulis itu sendiri. Penyusunan naskah dimulai ketika pengarang berada di Italia dalam kegiatan tamasya menulis bersama The Rockefeller Fondation Bellagio Center. Proses penggambaran kisah dilakukan dengan beberaa cara diantaranya berkaitan dengan pengalaman spiritual penulis semasa tinggal di kampung halaman, yaitu tanah Minang, kemudian 
pola asuh oleh kedua orang tuanya yang membesarkan penulis dengan nasihat-nasihat yang baik, yang sidikit banyaknya mempengaruhi penggambaran dalam kisah. Selanjutnya ialah dengan mengumpulkan sejumlah realita sosial yang lebih mendalam terkait kampung Minang yang menjadi latar dominan cerita serta pergolakan yang pernah terjadi di masanya dengan menjadikan beberapa orang sebagai narasumber penulis. Selanjutnya, tak lupa masukan-masukan dari orangorang terdekat Ahmad Fuasi yang terus memberikan masukan dan dukungan terhadap garapan naskah Anak Rantau ini yang sebelumnya hanya akan berkisah tentang rantau dan kampung halaman, namun setelah mejadi naskah yang layak dibaca, cerita banyak berkembang yang tidak pada sekadar hubungan rantau-kampung, tetapi tentang luka-obat, dendam-rindu, dan kekuatan memaafkan dan melupakan yang dikemas menarik dalam balutan judul Anak Rantau yang menajdikan tokoh sentral berusia remaja yaitu siswa SMP.

\section{KESIMPULAN}

Realisasi kesantunan berbahasa dalam novel Anak Rantau karya Ahmad Fuadi terlihat dalam kutipan dialog tokoh Hepi, Attar, Zen, Kakek, Nenek, dan Pandeka Luko sebagai tokoh sentral dalam cerita. Dalam novel tersebut ditemukan 5 maksim kesantun berbahasa Leech yakni, maksim kearifan, pujian, kerendahan hati, kesepakatan, dan maksim simpati. Sementara maksim kedermawanan tidak ditemukan dalam novel tersebut.

Realiasasi maksim kesantunan dalam novel Anak Rantau merupakan sesuatu hal yang menarik dan bernilai tinggi sehingga hal tersebut sesuai dengan kriteria sebagai bahan ajar di jenjang SMA. Selain itu, ditemukan pula gaya penggunaan bahasa tokoh yang sesuai dan mudah dipahami berdasarkan usia pelajar sebagai pembaca di sekolah. Aspek perkembangan psikologis tokoh yang digambarkan penuh dengan tanggung jawab, dan mengarah pada hal- hal positif sebagai tindakan pelajar yang dapat dijadikan roll model bagi kehidupan. Serta latar belakang sosial penokohan yang sedikitnya mewakili latar peseta didik, sehingga ketika menjadikan novel ini sebagai bahan ajar, maka diharapkan peserta didik dapat mendalami makna bacaan dengan merasakan pengalaman yang serupa dengan cerita. Penggunan bahan ajar ini diimplikasikan dalam kurikulum silubus Bahasa Indonesia Wajib kelas XII kurikulum 2016 KI. 3.9 KD.4.9.

\section{DAFTAR PUSTAKA}

Afrizal. 2015. Metode Penelitian Kualitatif Sebuah Upaya Mendukung

Penggunaan Penelitian Kualitatif dalam Berbagai Disiplin Ilmu. 
Jakarta: PT. Raja Grafindo Persada.

Alviyah, Iin. 2014. Kesantunan Berbahasa Dalam Novel Para Priyayi Karya Umar Kayam

Seloka Journal Pendidikan Bahasa dan Sastra Indonesia. Vol.3. No.2.

Beden, Sara \&Indriawati Zahid. Analysis of leech (1983) and grice's (1975)

Politeness: The Pattern and Structural of Politeness Language Manifestation In The Novel Melunas Rindu. Jurnal Pengajian Melayu. No. 26. Vol.1.

Chaer, Abdul. 2010. Kesantunan Berbahasa. Jakarta:Rineka Cipta.

Esten, Mursal. 2013. Kesusastraan Pengantar Teori dan Sejarah.

Bandung: Angkasa.

Etikawati, Dina. 2015. Kesantunan Tuturan antar Tokoh dalam Novel Nama Ku

Matahari Karya Remy Sylado. Jurnal Sastra Indonesia, Fakultas Bahasa dan Seni, Unversitas Negeri Semarang.

Fuadi, Ahmad. 2018. Anak Rantau. Jakarta: PT. Falcon.

Ismawati, Esti. 2012. Metode Penelitian Pendidikan Bahasa dan Sastra.

Yogyakarta: Penerbit Ombak.

Kamini, Ni Nyoman. 2011. Teori Pengkajian Prosa Fiksi dan Drama. Bali: Pustaka

Larasan. Leech, Geoffrey. 2008. Prinsip-Prinsip Pragmatik, terj. Oka, M.A., Jakarta:

UI

Press.

Mulyadi, Yadi, dkk, 2016, Intisari Sastra Indonesia. Bandung: Yrama Widiya.

Nurgiyantoro, Burhan . 2015. Teori Pengkajian Fiksi, Yogyakarta: Gadjah Mada

University

Press Anggota Ikapi.

Pangaribuan, Tagor . 2008. Paradigma Bahasa. Yogyakarta:

Graha Ilmu. Pranowo. 2012. Berbahasa Secara Santun.

Yogyakarta: Pustaka Pelajar.

Yola, Maulina, dkk. 2015. Kesantunan Berbahasa Dalam Novel 99 Cahaya di

Langit Eropa Karya Hanum Salsabiela Rais dan Rangga Almahendra.

Journal Online Mahasiswa

Fakultas Keguruan dan Ilmu Pendidikan Universitas Negeri Riau. Vol.2. No.1 . 